\title{
PREVALENCE OF THYROID CARCINOMA IN CLINICALLY DIAGNOSED MULTINODULAR GOITRE IN A TERTIARY CARE CENTRE- A RETROSPECTIVE DESCRIPTIVE STUDY
}

\author{
Premlal Ayyappan Prasanna1, Rishikesan Nair Kavsthubham Venugopalan Nair ${ }^{2}$, Resmi Madhusoodanan Santhakumar ${ }^{3}$
}

${ }^{1}$ Associate Professor, Department of Plastic Surgery, Government Medical College, Thiruvananthapuram.

${ }^{2}$ Associate Professor (CAP), Department of General Surgery, Government Medical College, Thiruvananthapuram.

3Junior Resident, Department of Community Medicine, Government Medical College, Thiruvananthapuram.

\section{ABSTRACT}

\section{BACKGROUND}

Multinodular goitre is a very common, usually benign thyroid disorder, but sometimes occurrence of malignancy is reported as a histopathological surprise. Longstanding multinodular goitre has been suggested as a predisposing factor, since areas with iodine deficiency related endemic goitre have a high incidence of follicular carcinoma. In this study, we have evaluated the prevalence of incidental or occult carcinoma and thyroiditis in thyroidectomies performed for clinically benign multinodular goitres. We also attempted to find if a more radical approach is needed in the management of clinically benign multinodular goitres.

In this study, we aimed to identify the prevalence of carcinoma and thyroiditis clinically and on fine needle aspiration cytologically looking benign multinodular goitres. This study also intended to identify the relation of Sex, Age and Duration of illness from thyroid carcinoma.

\section{MATERIALS AND METHODS}

This is a retrospective descriptive study of patients with clinically and ultrasonographically proved multinodular goitre treated in one year. Fine Needle Aspiration Cytology proved malignancy is excluded from the study population. All the thyroidectomy specimens were pathologically studied and correlated with clinical findings.

\section{RESULTS}

Out of 303 patients, 90.4\% (274) were females and 9.6\% (29) were males. 50.8\% were below 40 years and $49.2 \%$ were above 40 years. Duration of illness is 1 - 20 years. 64.4\% were pathologically Benign Multinodular goitre only. 8\% was having malignancy along with Multinodular goitre, of which $7.3 \%$ was papillary carcinoma and $0.7 \%$ was Follicular carcinoma.

\section{CONCLUSION}

It is found that prevalence of carcinoma in clinically multinodular goitres is 8\%, which was not detected by Fine Needle Aspiration Cytology. No correlation with duration of illness. Incidence of Papillary Carcinoma is more in clinically benign Multinodular goitres than Follicular Carcinoma against what is said in Western literature.

\section{KEYWORDS}

Multinodular Goitre, Papillary Carcinoma, Follicular Carcinoma, Thyroiditis, Thyroidectomy.

HOW TO CITE THIS ARTICLE: Prasanna PA, Nair RNKV, Santhakumar RM. Prevalence of thyroid carcinoma in clinically diagnosed multinodular goitre in a tertiary care centre- a retrospective descriptive study. J. Evolution Med. Dent. Sci. 2017;6(53):3996-4001, DOI: $10.14260 /$ Jemds/2017/864

\section{BACKGROUND}

Enlargement of thyroid or goitre is the most common manifestation of thyroid disease. ${ }^{1}$ Diffuse and multinodular goitre reflect impaired synthesis of thyroid hormone, most often caused by dietary iodine deficiency. Impairment of thyroid hormone synthesis leads to compensatory rise in serum TSH level, which in turn causes hypertrophy and hyperplasia of thyroid follicular cells and ultimately gross enlargement of thyroid gland. This compensatory increase in functional mass of the gland is able to overcome the hormone deficiency ensuring euthyroid state. The degree of thyroid enlargement is proportional to the level and duration of thyroid hormone deficiency.2,3

Financial or Other, Competing Interest: None.

Submission 22-04-2017, Peer Review 16-05-2017,

Acceptance 22-05-2017, Published 03-07-2017.

Corresponding Author:

Dr. Premlal Ayyappan Prasanna,

"Nrithya", Trwa-S, Thaliyal,

Karamana P.O., Thiruvananthapuram.

E-mail: drpremlalap@gmail.com

DOI: $10.14260 /$ jemds $/ 2017 / 864$
With time, recurrent episodes of hyperplasia and involution combine to produce irregular enlargement of thyroid termed multinodular goitre. Virtually, all longstanding simple goitre convert into multinodular goitre. ${ }^{4}$ They may be nontoxic or may induce thyrotoxicosis (toxic multinodular goitre). Multinodular goitre may produce the most extreme thyroid enlargement and may be mistaken for neoplastic involvement than any other form of thyroid disease. Because they derive from simple goitre, they occur in sporadic and endemic forms, having the female preponderance distribution and presumably the same origins but affecting older individuals because they are late complications.5,6

It is believed that multinodular goitre may arise because of the variation among follicular cells in response to external stimuli, such as trophic hormones. If some cells in a follicle have a growth advantage, perhaps because of intrinsic genetic abnormalities similar to those that give rise to adenomas, those cells will develop into clones of proliferating cells. This may result in the formation of a nodule whose continued growth can be autonomous without an external stimulus. ${ }^{7}$ Consistent with this model both monoclonal and 
polyclonal nodules coexist within the same multinodular goitre, the latter presumably having arisen owing to acquisition of a genetic abnormality favouring growth. Mutation in proteins of TSH signalling pathway that lead to constitutive activation of this pathway have been identified in a subset of autonomous thyroid nodules. With uneven follicular hyperplasias, generation of new follicles and uneven accumulation of colloid, tension and stresses are produced that lead to ruptures of follicle and vessels followed by haemorrhages, scarring and sometimes calcifications. The scarring adds to the tension and in this cyclical manner nodularity appears. Moreover, the preexisting stromal frame work may enclose areas of expanded parenchyma contributing to the nodularity. $.8,9,10,11$

About $4 \%$ to $7 \%$ of the population has nodular thyroid disease. Approximately, $4 \%$ of these nodules are malignant and account for about $1 \%$ of all cancers. The female-to-male ratio of thyroid nodules is $6.5: 1.5 .12,13$

Around 2000 patients are admitted in all surgical units of Medical College, Trivandrum every year for thyroid surgery. Of this, more than half are admitted with multinodular goitre.

Multinodular goitre is a very common, usually benign, thyroid disorder. However variable and sometimes surprisingly high occurrence of malignancy has been reported in many a surgical series. ${ }^{14,15,16}$ Multinodularity of goitre should no longer be considered an indicator of probable benign disease. Longstanding multinodular goitre has been suggested as predisposing factor in some cases, since areas with iodine deficiency related endemic goitre have a high incidence of follicular carcinoma. ${ }^{17,18,19,20}$

Multinodular goitre cannot be considered as a condition predisposing to cancer, but it may harbour a cancer. Since neoplastic transformation is a multistep process that results in a continuous spectrum from the normal (physiological) state to a fully established neoplasm. ${ }^{21,22}$

Thyroid Carcinoma (TC) is a relatively rare tumour, but it represents the most frequent form of cancer of the endocrine glands. Epidemiologically ascertained risk factors are ionising radiation, the presence of thyroid adenoma and Multinodular Goitre (MNG).23,24,25,26

The incidence of thyroid carcinoma in thyroiditis and multinodular goitre has been debated and the possibility of autoimmune and immunological mechanisms in the aetiopathogenesis of carcinoma, particularly papillary type stimulating lymphocytic infiltration has been suggested. Histologically, it is difficult to differentiate lymphocytic infiltrate surrounding thyroid carcinoma from lymphocytic thyroiditis. It is still unclear whether thyroiditis is induced secondarily by thyroid carcinoma or thyroiditis predisposes thyroid gland to development of carcinoma. $2,27,28,29,30$

The present study is an attempt to evaluate the prevalence of incidental or occult carcinoma and thyroiditis in thyroidectomies performed for benign nodular thyroid disease. The type of carcinoma associated with benign nodular disease and the duration of the nodular disease is also taken into consideration. Another factor which is of importance in this study is the fact that clinically solitary nodules may actually be a dominant nodule in a multinodular goitre. ${ }^{31,32}$ The study also attempts to find if a more radical approach including a change from subtotal to total or near total thyroidectomy decreased the rate of subsequent completion thyroidectomy for occult carcinoma. $33,34,35,36,37$

\section{MATERIALS AND METHODS}

This is a retrospective descriptive study of patients with clinically and ultrasonographically proved multinodular goitre diagnosed and treated in all surgical units of Medical College, Trivandrum during a period of 1 year from January 2008 to December 2008. Each patient's symptoms and signs, investigations, treatment given and histopathology report were entered in the proforma with details of clinical examination in relation to the thyroid swelling. All patient's basic investigations like complete haemogram, blood sugar, blood urea, serum cholesterol, routine urine examination, chest x-ray, ECG, radiograph of neck, thyroid function tests, tissue diagnosis obtained by Fine Needle Aspiration Cytology (FNAC) were taken for analysis. ${ }^{38,39,31}$ Ultrasonogram of neck was done in most of the patients. ${ }^{40}$ All the patients underwent surgery, either hemithyroidectomy, subtotal thyroidectomy or near total/total thyroidectomy $41,42,43$ and all operated specimens were subjected to detailed histopathological examination in the Department of Pathology, Medical College, Trivandrum. All histopathology reports were taken and analysed. ${ }^{44,45,8,46}$

Study participants were patients with clinically diagnosed multinodular goitre who underwent surgery in all surgical units of Medical College, Trivandrum. Patients diagnosed to have toxic goitre and FNAC-proven thyroiditis and malignancy were excluded from the study. So, only clinically and cytologically-proven multinodular goitre were included.

Preoperative and post-operative complications were analysed. All observations were analysed and compared with other studies.

\section{Diagnostic Workup}

In the study, the following investigations were done in all patients which includes blood routine examination, urine routine examination, blood sugar, blood urea, serum creatinine, plain $\mathrm{x}$-ray neck, chest $\mathrm{x}$-ray, indirect laryngoscopy and Fine Needle Aspiration Cytology.47,48,49 Most of the patients had done ultrasonogram of neck. ${ }^{50}$ All the patients had their thyroid function tests- T3, T4 and TSH done before and after surgery. $51,52,53$

Radionucleotide scanning was not done for any patient due to non-availability of the facility in our hospital. ${ }^{54,55,56}$ Fine needle aspiration cytology represents a reliable method of providing tissue diagnosis and has been done for all patients and subjects with FNAC-proven malignancy were excluded from the study.

\section{RESULTS}

Out of 303 patients studied, 274 were females (90.4\%) and 29 were males $(9.6 \%)$ [Table 1]. Out of this 154 was below age of 40 years $(50.8 \%)$ and 149 was above the age of 40 years $(49.2 \%)$ [Table 1] with a range of 20 years to 72 years. The total duration of illness ranged from 1 year to 20 years; 227 patients were having a duration of $<5$ years $(74.9 \%), 69$ patients were between 5 - 10 years $(22.8 \%)$ and 7 were having above 10 years' duration (2.3\%) [Table 1]. Near Total/ Total Thyroidectomy was the most common surgical procedure performed $(n=177,58.4 \%)$. Hemithyroidectomy was done for 8 patients $(2.6 \%)$ and subtotal thyroidectomy was done for 118 patients (38.9\%) [Table 1]. 
Multinodular goitre/ Nodular colloid goitre was the most common finding in histopathology $(n=195,64.4 \%)$. Multinodular goitre with cellular nodule was the report obtained for 40 patients (13.2\%) and Multinodular goitre with thyroiditis was obtained for 44 patients (14.5\%). Other reports included Multinodular goitre with papillary carcinoma $(n=22,7.3 \%)$ and Multinodular goitre with follicular carcinoma $(n=2,0.7 \%)$. So, the total number of malignancies reported was for 24 patients; (22 papillary carcinoma +2 follicular carcinoma), a total of $8 \%$ (Table 2).

Out of the patients reported to have multinodular goitre $(\mathrm{n}=195), 22$ were men $(11.3 \%)$ and 173 were women (88.7\%) [Table 3]. Among the patients having multinodular goitre with cellular nodule $(n=40)$, two were men $(5 \%)$ and 38 were women (95\%), and among patients having multinodular goitre with papillary carcinoma two were men (9.1\%) and 20 were women $(90.9 \%)$. Both the patients with multinodular goitre with follicular carcinoma were women. Of the 44 patients having multinodular goitre with thyroiditis, 3 were males (6.8\%) and 41 were females (93.2\%) [Table 3]. Of the 195 patients having multinodular goitre alone, 98 patients $(50.3 \%)$ are $<40$ years and 97 patients are $>41$ years of age (49.7\%) [Table 3]. Of the 40 patients having multinodular goitre with cellular nodule $23(57.5 \%)$ were < 40 years and $17(42.5 \%)$ patients were $>40$ and among 22 patients having multinodular goitre with papillary carcinoma 11 were $<40$ years $(50 \%)$ and 11 were $>41$ years of age (50\%) [Table 3]. Both the patients having multinodular goitre with follicular carcinoma both were below 40 years. Of the 44 patients having multinodular goitre with thyroiditis 20 $(45.5 \%)$ were $<40$ years and $24(54.5 \%)$ were $>40$ years (Table 3).

Of the 195 patients having multinodular goitre alone 5 patients underwent hemithyroidectomy (2.6\%), 72 patients underwent subtotal thyroidectomy (36.9\%) and 118 patients underwent near total/ total thyroidectomy (60.5\%) [Table 4]. Of the 40 patients having multinodular goitre with cellular nodule 2 patients underwent hemithyroidectomy (5\%), 16 patients underwent subtotal thyroidectomy (40\%) and 22 patients underwent near total/ total thyroidectomy (55\%). Of the 22 patients having multinodular goitre with papillary carcinoma 1 patient underwent hemithyroidectomy (4.5\%), 9 patients underwent subtotal thyroidectomy (40.9\%), 12 patients underwent near total/ total thyroidectomy (54.5\%). Of the 2 patients having multinodular goitre with follicular carcinoma, one underwent subtotal thyroidectomy (50\%) and other underwent near total thyroidectomy (50\%). Of the 44 patients having multinodular goitre with thyroiditis, 20 patients underwent subtotal thyroidectomy (45.5\%) and rest 24 underwent near total/ total thyroidectomy (54.5\%) [Table 4].

\begin{tabular}{|c|c|c|c|}
\hline Variable & Group & $\begin{array}{c}\text { No. of } \\
\text { Patients } \\
(n=303)\end{array}$ & $\%$ \\
\hline Age & Up to 40 years & 154 & $50.8 \%$ \\
\hline Sex & Female & 274 & $90.4 \%$ \\
\hline \multirow{3}{*}{$\begin{array}{l}\text { Duration in } \\
\quad \text { Years }\end{array}$} & $<5$ & 227 & $74.9 \%$ \\
\hline & $5-10$ & 69 & $22.8 \%$ \\
\hline & $>10$ & 7 & $2.3 \%$ \\
\hline \multirow{3}{*}{$\begin{array}{c}\text { Management } \\
\text { Given }\end{array}$} & Hemithyroidectomy & 8 & $2.6 \%$ \\
\hline & \begin{tabular}{|c|} 
Subtotal \\
Thyroidectomy
\end{tabular} & 118 & $38.9 \%$ \\
\hline & $\begin{array}{l}\text { Near Total/ Total } \\
\text { Thyroidectomy }\end{array}$ & 177 & $58.4 \%$ \\
\hline
\end{tabular}

\begin{tabular}{|c|c|c|}
\hline Histopathological Report & No. of Patients & Percentage \\
\hline $\begin{array}{c}\text { Multinodular goitre/ nodular } \\
\text { colloid goitre }\end{array}$ & 195 & $64.4 \%$ \\
\hline $\begin{array}{c}\text { Multinodular goitre with } \\
\text { cellular nodule }\end{array}$ & 40 & $13.2 \%$ \\
\hline $\begin{array}{c}\text { Multinodular goitre with } \\
\text { papillary carcinoma }\end{array}$ & 22 & $7.3 \%$ \\
\hline $\begin{array}{c}\text { Multinodular goitre with } \\
\text { follicular carcinoma }\end{array}$ & 2 & $0.7 \%$ \\
\hline $\begin{array}{c}\text { Multinodular goitre with } \\
\text { thyroiditis }\end{array}$ & 44 & $14.5 \%$ \\
\hline Table 2.
\end{tabular}

Table 2. Histopathological Diagnosis of Study Participants

\begin{tabular}{|c|c|c|c|c|c|c|}
\hline \multirow[t]{2}{*}{ Category } & \multicolumn{5}{|c|}{ Histopathological Report } & \multirow[t]{2}{*}{$P$ value } \\
\hline & $\begin{array}{c}\text { Multinodular } \\
\text { Goitre/ Nodular } \\
\text { Colloid Goitre } \\
(n=195) \\
\end{array}$ & $\begin{array}{l}\text { Multinodular Goitre } \\
\text { with Cellular Nodule } \\
\qquad(n=40)\end{array}$ & $\begin{array}{c}\text { Multinodular Goitre } \\
\text { with Papillary } \\
\text { Carcinoma }(n=22)\end{array}$ & $\begin{array}{c}\text { Multinodular } \\
\text { Goitre with } \\
\text { Follicular } \\
\text { Carcinoma }(\mathrm{n}=2)\end{array}$ & \begin{tabular}{|c|} 
Multinodular \\
Goitre with \\
Thyroiditis \\
$(\mathrm{n}=44)$ \\
\end{tabular} & \\
\hline Male & 22 & 2 & 2 & 2 & 3 & \\
\hline Female & 173 & 38 & 20 & 0 & 41 & \\
\hline$<40$ yrs. & 98 & 23 & 11 & 2 & 20 & \\
\hline$>41$ yrs. & 97 & 17 & 11 & 0 & 24 & \\
\hline
\end{tabular}




\begin{tabular}{|c|c|c|c|}
\hline Surgery Done & HPR & Frequency & $\%$ \\
\hline \multirow{5}{*}{ Hemithyroidectomy } & MNG & 5 & $62.5 \%$ \\
\hline & \begin{tabular}{|c|} 
MNG with \\
Cellular Nodule
\end{tabular} & 2 & $25 \%$ \\
\hline & $\begin{array}{c}\text { MNG with } \\
\text { papillary } \\
\text { carcinoma } \\
\end{array}$ & 1 & $12.5 \%$ \\
\hline & $\begin{array}{l}\text { MNG with } \\
\text { follicular } \\
\text { carcinoma }\end{array}$ & 0 & - \\
\hline & $\begin{array}{l}\text { MNG with } \\
\text { thyroiditis }\end{array}$ & 0 & - \\
\hline \multirow{5}{*}{$\begin{array}{l}\text { Subtotal } \\
\text { Thyroidectomy }\end{array}$} & MNG & 72 & $61 \%$ \\
\hline & $\begin{array}{c}\text { MNG with } \\
\text { Cellular Nodule }\end{array}$ & 16 & $13.5 \%$ \\
\hline & $\begin{array}{c}\text { MNG with } \\
\text { papillary } \\
\text { carcinoma }\end{array}$ & 9 & $7.6 \%$ \\
\hline & $\begin{array}{l}\text { MNG with } \\
\text { follicular } \\
\text { carcinoma }\end{array}$ & 1 & $0.8 \%$ \\
\hline & $\begin{array}{l}\text { MNG with } \\
\text { thyroiditis }\end{array}$ & 20 & $16.9 \%$ \\
\hline \multirow{5}{*}{$\begin{array}{l}\text { Near Total/Total } \\
\text { Thyroidectomy }\end{array}$} & MNG & 118 & $66.6 \%$ \\
\hline & $\begin{array}{c}\text { MNG with } \\
\text { cellular nodule }\end{array}$ & 22 & $12.4 \%$ \\
\hline & $\begin{array}{c}\text { MNG with } \\
\text { papillary } \\
\text { carcinoma }\end{array}$ & 12 & $6.7 \%$ \\
\hline & $\begin{array}{l}\text { MNG with } \\
\text { follicular } \\
\text { carcinoma }\end{array}$ & 1 & $0.5 \%$ \\
\hline & $\begin{array}{l}\text { MNG with } \\
\text { thyroiditis }\end{array}$ & 24 & $13.5 \%$ \\
\hline
\end{tabular}

\section{DISCUSSION}

In this study, prevalence of carcinoma in clinically multinodular goitre was found to be $8 \%$. All these patients studied were subjected to Fine Needle Aspiration Cytology before surgery and none of them was reported to be malignant even though Fine Needle Aspiration Cytology was thought to be much sensitive to diagnose papillary carcinoma thyroid. This may be attributed to the fact that FNAC obtained were not from the involved areas. Of the $8 \%$ of malignancies detected, $7.3 \%$ was papillary carcinoma and $0.7 \%$ was follicular carcinoma and the result is comparable with those from various studies but different from studies in Western literature.

Among the patients with multinodular goitre with papillary carcinoma, $90.9 \%$ were females and $9.1 \%$ were males which shows a significant female preponderance.

Among the patients with multinodular goitre with follicular carcinoma, $100 \%$ were females.

$13.2 \%$ of patients operated were having a cellular nodule in histopathology and $14.5 \%$ of patients were having thyroiditis co-existing with multinodular goitre. $93.2 \%$ of patients having thyroiditis were females and $6.8 \%$ were males.

When age group is taken into account, there is no much difference in occurrence of malignancy between the age groups $<40$ or $>40$.
We could not find out any correlation of malignancy with duration of illness. But in Western literatures, it has been stated that longstanding multinodular goitres has greater association with follicular carcinoma thyroid.

Among those patients with multinodular goitre with papillary carcinoma being operated, hemithyroidectomy was done for $4.5 \%, 41 \%$ of the patients had subtotal thyroidectomy and $54.5 \%$ of patients had near total/total thyroidectomy done.

Of the patients reported to have MNG with follicular carcinoma, 50\% had subtotal thyroidectomy done and 50\% had total thyroidectomy done.

\section{CONCLUSION}

The following conclusions were reached at the end of this study after comparing and analysing the data collected-

1. The prevalence of malignancy in multinodular goitre in the study group was $8 \%$.

2. $7.3 \%$ of the study group had papillary carcinoma and $0.7 \%$ of the study group had follicular carcinoma showing an increased prevalence of papillary carcinoma compared to follicular carcinoma in multinodular goitres.

3. The prevalence of the thyroiditis noted in the study, population was $14.5 \%$.

4. A definite female preponderance was found in malignant changes and $83 \%$ of the malignancy reported was females.

5. No correlation between duration of illness and prevalence of malignancy in multinodular goitre could be noted in this study. Hence, occult malignancy can occur in tumours with short duration also. So surgery should not be delayed thinking that it is benign disease.

6. There is no statistically significant difference in prevalence of malignancy among different age groups in the study.

7. Considering the high prevalence of malignancy in clinically benign multinodular goitre, near total/ total thyroidectomy could be the appropriate surgery of choice, since the patients undergoing hemithyroidectomy or subtotal thyroidectomy will have to be subjected to completion thyroidectomy if the histopathology report comes as malignant.

\section{REFERENCES}

[1] Cuschieri A, Steele R, Moossa AR. Essential surgical practice. $4^{\text {th }}$ edn. Basic surgical training. Taylor \& Francis 2000:P 606.

[2] Anderson's pathology. 10 th edn. In: Damjanov I, Linder J 2017. Available from: https://docs.google.com/document/d/1LY7urOZLzC2 9BCqGYA8IVo41U55LphrlBqitQPDRTeI/edit?usp=em bed_facebook.

[3] Goiter \& thyroid nodules 2017. Available from: http://surgery.ucsf.edu/conditions procedures/goiter.aspx.

[4] Thomas WEG, Reed MWR, Wyatt MG. Oxford textbook of fundamentals of surgery. Oxford, New York: Oxford University Press 2016:P 832. 
[5] Robbins SL, Kumar V, Cotran RS. Robbins and cotran pathologic basis of disease. Philadelphia, PA: Saunders/Elsevier 2010. Available from: http://www.clinicalkey.com/dura/browse/bookChap ter/3-s2.0-B9781437707922X50019.

[6] Willis RA. Pathology of tumours 1967:P 1078.

[7] Hamburger JI. Solitary autonomously functioning thyroid lesions. Diagnosis, clinical features and pathogenetic considerations. Am J Med 1975;58(6):740-8.

[8] Johnson CD. Recent advances in surgery 32. CRC Press $2009 . \quad$ Available from: https://www.crcpress.com/Recent-Advances-inSurgery-32/Johnson-

Taylor/p/book/9781853158797.

[9] Bailey H, Love RJM. Bailey and love's short practice of surgery. Chapman \& Hall Medical 1992:P 1519.

[10] Townsend CM, Beauchamp RD, Evers BM, et al. Sabiston textbook of surgery E-book. 19th edn. Elsevier Health Sciences 2012:P 7891.

[11] Hall J. Guyton and hall textbook of medical physiology. $12^{\text {th }}$ edn. Elsevier 2006:P 1160.

[12] Frauenhoffer CM, Patchefsky AS. Thyroid carcinoma. A clinical and pathological study of 125 cases. Cancer 1979;43(6):2414-21.

[13] Gandolfi PP, Frisina A, Raffa M, et al. The incidence of thyroid carcinoma in multinodular goiter: retrospective analysis. Acta Biomed 2004;75(2):1147.

[14] al-Saleh MS, al-Kattan KM. Incidence of carcinoma in multinodular goitre in Saudi Arabia. J R Coll Surg Edinb 1994;39(2):106-8.

[15] Miccoli P, Minuto MN, Galleri D, et al. Incidental thyroid carcinoma in a large series of consecutive patients operated on for benign thyroid disease. ANZ J Surg 2006;76(3):123-6.

[16] Chang KW. Study on the incidence of carcinoma in multinodular goitre by department of surgery university hospital, Lembah Pantai, Kuala Lumpur, Malaysia. Tumori 1990;76(3):255-7.

[17] Terzioglu T, Tezelman S, Onaran Y, et al. Concurrent hyperthyroidism and thyroid carcinoma. British Journal of Surgery 1993;80(10):1301-2.

[18] Sengupta. Spectrum of goitrous lesions in patients at a tertiary care center of Sikkim 2017. Available from: http://www.smjonline.org/article.asp?issn=1118-

8561;year=2014; volume=17; issue=3; spage=112; ; pag e=116; aulast=Sengupta.

[19] Efremidou EI, Papageorgiou MS, Liratzopoulos N, et al. The efficacy and safety of total thyroidectomy in the management of benign thyroid disease: a review of 932 cases. Can J Surg 2009;52(1):39-44.

[20] Corapcioglu D, Sak SD, Delibasi T, et al. Papillary microcarcinomas of the thyroid gland and immunohistochemical analysis of expression of p53 protein in papillary microcarcinomas. J Transl Med 2006;4:28.

[21] Pelizzo MR, Toniato A, Piotto A, et al. Retrospective analyzis on a consecutive series of 539 thyroidectomies performed for MNG over a short period of time of 3 years. J R Coll Surg Edinb 1994;39(2):106-8.
[22] Cerci C, Cerci SS, Eroglu E, et al. Thyroid cancer in toxic and non-toxic multinodular goiter. J Postgrad Med 2007;53(3):157-60.

[23] Full text of snell clinical anatomy by regions. $9^{\text {th }}$ edn. $2012 . \quad$ Available from: https://archive.org/stream/pdfy-d-

PFUmAhPcw_n7EV/snell\%20clinical\%20anatomy\%2 0by\%20regions\%209th\%20ed\%202012_2_djvu.txt.

[24] Hamilton bailey's physical signs: demonstrations of physical signs in clinical surgery. $19^{\text {th }}$ edn. CRC Press 2016. Available from: https://www.crcpress.com/Hamilton-BaileysPhysical-Signs-Demonstrations-of-Physical-Signs-in Clinical/Lumley-DCruz-Hoballah-ScottConnor/p/book/9781444169188.

[25] Orell SR, Gregory S. Orell and sterrett's fine needle aspiration cytology. $5^{\text {th }}$ edn. Elsevier 1995.

[26] Hirshoren N, Neuman T, Udassin R, et al. The imperative of the sistrunk operation: review of 160 thyroglossal tract remnant operations. Otolaryngol Head Neck Surg 2009;140(3):338-42.

[27] AI-Sayer HM, Krukowst, ZH, Williams VNM, et al. FNAC in isolated thyroid swelling. BMJ 1985;290:1490-2.

[28] Ross LGL, Fiore BA, Giuffrida D, et al. Evaluation of the fine needle aspiration biopsy into the preoperative selection of cold thyroid nodules. Concern 1991;67:2137-41.

[29] Lowbagen T, Granberg PO, Lundel G, et al. Aspiration cytology in nodule of T.G respected to be malignant 1979.

[30] Nutz V, Larena-Avellaneda A, Wunsch E, et al. Malignomhäufigkeit und operationsindikation der knotenstruma im endemiegebiet. DMW - Dtsch Med Wochenschr 1984;109(35):1319-21.

[31] Dean DS, Gharib H. Fine-Needle aspiration biopsy of the thyroid gland. MDText.com Inc 2015. Available from: https://www.ncbi.nlm.nih.gov/books/NBK285544/.

[32] Dreimane D, Varma SK. Common childhood thyroid disorders. Indian Journal of Pedeatrics 1997;64(1):310.

[33] Rao RS, Fakih AR, Mehta AR, et al. Completion thyroidectomy for thyroid carcinoma. Head Neck Surg 1987;9(5):284-6.

[34] Alderson PO, Sumner HW, Siegel BA. The single palpable thyroid nodule. Cancer 1976;37:258-65.

[35] Astwood EB, Cassidy CE, Aurbach GD. Treatment of goiter and thyroid nodules with thyroid. JAMA 1960;174:459-64.

[36] Farquharson M. Farquharson's textbook of operative general surgery. $9^{\text {th }}$ edn. London: Hodder Arnold 2005.

[37] Kirk RM, Winslet MC. Essential general surgical operations. Elsevier Health Sciences 2007:P 430.

[38] Vasudev V, AL H, B R, et al. Efficacy and pitfalls of FNAC of thyroid lesions in children and adolescents. J Clin Diagn Res 2014;8(1):35-8.

[39] Singer A, Khan A, Deery ARS, et al. Cervical and lower genital tract precancer: diagnosis and treatment. $3^{\text {rd }}$ edn. John Wiley \& Sons 2014:P 304.

[40] Cox MC, Raj S. STN - a prospective evaluation of nuclear scanning SVSG. Br J Surg 1991;78:90-3. 
[41] Surgery of the thyroid and parathyroid glands. $2^{\text {nd }}$ edn. Available from: https://www.elsevier.com/books/surgery-of-thethyroid-and-parathyroid-glands/randolph/978-14377-2227-7.

[42] Hermus AR, Huysmans DA. Treatment of benign nodular thyroid diseases. New England journal of medicine 1998;338:1438-47.

[43] Nagori LF, Algotor MJ. Solitary solid thyroid nodule. Int J of Surgery 1982;54(2):73-8.

[44] Hume DM, Schwartz SI. Principles of surgery. Seymour I, Schwartz, Hume DM, (eds). McGraw-Hill 1969:P 672.

[45] Hellman S, Steven A. Rosenberg VTD. Cancerprinciples-and-practice-of-oncology-6e 2017. Available from: https://oncouasd.files.wordpress.com/2014/09/canc er-principles-and-practice-of-oncology-6e.pdf.

[46] Marlow RSBS. Operative surgery: head and neck and clearance of lymph nodes. Vascular surgery. Endocrine glands. FA Davis Company 1957:P 406.

[47] Walfish PG, Hazani E, Strawbridge HT, et al. Combined ultrasound and needle aspiration cytology in the assessment and management of hypofunctioning thyroid nodule. Ann Intern 1977;87(3):270-4.
[48] Spencer RP. Therapy in nuclear medicine. Grune \& Stratton 1978;133(1):398.

[49] Roti E, Uberti DEC, Bondanelli $\mathrm{M}$, et al. Thyroid papillary microcarcinoma: a descriptive and metaanalysis study. Eur J Endocrinol 2008;159(6):659-73.

[50] Tezelman S, Giles Y, Tunca F, et al. Diagnostic value of dynamic contrast medium-enhanced magnetic resonance imaging in preoperative detection of thyroid carcinoma. Arch Surg 2007;142(11):1036-41.

[51] Celani MT, Maraini G. T4 Suppression therapy in medical management of STN. Acta Endocrinol 1990;123:603-8.

[52] Cheung PS, Lee JM, Boey JH. Thyroxine suppressive therapy of benign solitary thyroid nodules: a prospective randomized study. W J Surg 1989;13(6):818-22.

[53] Reverter JL, Salimas LI. Suppressive therapy with levothyroxine for STN. CLIN sndorinol 1992;36:25-8.

[54] Lufkin RB, Borges A, Villablanca P. Teaching atlas of head and neck imaging. Thieme 2000:P 496.

[55] Matheson NA. The diagnosis of thyroid swelling recent advances in surgery. $12^{\text {th }}$ edn. Burgh 1986:179-97.

[56] Psarras A. The single thyroid nodule. Br J Surg 1972;59(7):545-8. 